
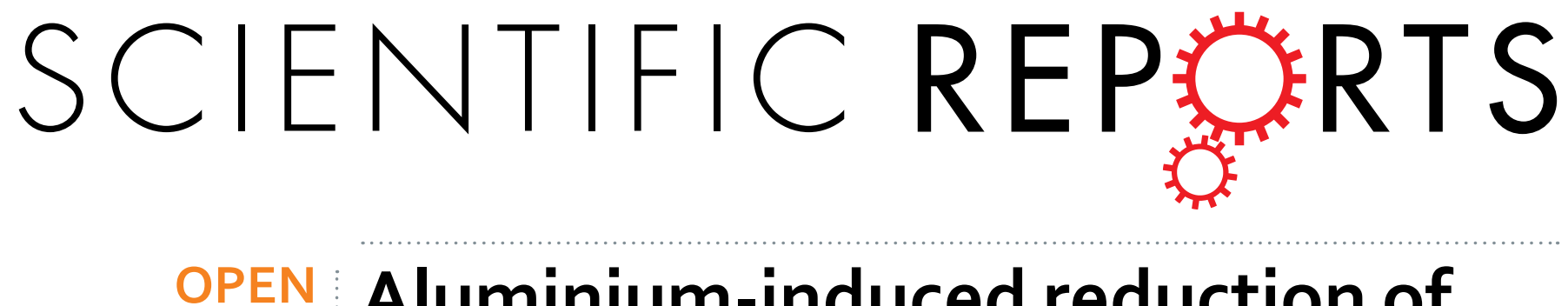

\title{
Aluminium-induced reduction of
} plant growth in alfalfa (Medicago sativa) is mediated by interrupting

Received: 16 April 2016

Accepted: 29 June 2016

Published: 20 July 2016

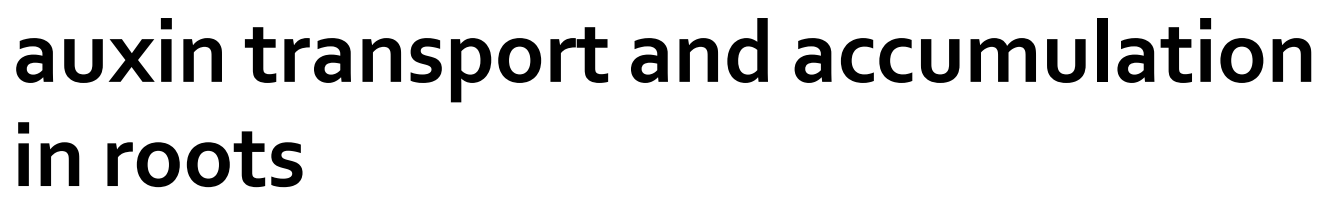

Shengyin Wang ${ }^{1}$, Xiaoyan Ren ${ }^{1}$, Bingru Huang ${ }^{2}$, Ge Wang ${ }^{3}$, Peng Zhou ${ }^{1}$ \& Yuan An ${ }^{1,4}$

The objective of this study was to investigate $\mathrm{Al}^{3+}{ }^{3}$-induced IAA transport, distribution, and the relation of these two processes to $\mathrm{Al}^{3+}$-inhibition of root growth in alfalfa. Alfalfa seedlings with or without apical buds were exposed to 0 or $100 \mu \mathrm{M} \mathrm{AlCl}_{3}$ and were foliar sprayed with water or $6 \mathrm{mg} \mathrm{L}^{-1}$ IAA. Aluminium stress resulted in disordered arrangement of cells, deformed cell shapes, altered cell structure, and a shorter length of the meristematic zone in root tips. Aluminium stress significantly decreased the IAA concentration in apical buds and root tips. The distribution of IAA fluorescence signals in root tips was disturbed, and the IAA transportation from shoot base to root tip was inhibited. The highest intensity of fluorescence signals was detected in the apical meristematic zone. Exogenous application of IAA markedly alleviated the $\mathrm{Al}^{3+}$-induced inhibition of root growth by increasing IAA accumulation and recovering the damaged cell structure in root tips. In addition, $\mathrm{Al}^{3+}$ stress upregulated expression of $A U X 1$ and $P I N 2$ genes. These results indicate that $A l^{3+}$-induced reduction of root growth could be associated with the inhibitions of IAA synthesis in apical buds and IAA transportation in roots, as well as the imbalance of IAA distribution in root tips.

Aluminium (Al) is the most abundant metal and is widely distributed in nature in the form of silicates or other deposits ${ }^{1}$. A high content of soluble $\mathrm{Al}^{3+}$ in soils with a $\mathrm{pH}$ below 5 is very phytotoxic and becomes a major limiting factor of plant productivity in acidic soils ${ }^{2}$. The most obvious symptom of $\mathrm{Al}^{3+}$ toxicity is the inhibition of root growth ${ }^{3}$. Excessive $\mathrm{Al}^{3+}$ inhibits both cell elongation and division in roots, leading to swollen root apices with poor or no root-hair development. Several studies suggested that this may be caused by the interaction of $\mathrm{Al}^{3+}$ with signal transduction pathways regulating cell growth. It has been shown that $\mathrm{Al}^{3+}$ may be bound to the plasma membrane, disturbing ion transport and homeostasis as well as blocking $\mathrm{Ca}^{2+}$-dependent signalling cascades ${ }^{4}$. The binding of $\mathrm{Al}^{3+}$ to the plasma membrane may also lead to a disruption of membrane function and the promotion of oxidative stress, which prevent the release of secondary signalling molecules and influence the organization of the cell cytoskeleton ${ }^{5,6}$. In addition, $\mathrm{Al}^{3+}$ stress induces callose production in plasmodesmata, which may block auxin or indole acetic acid (IAA) transport through the symplast and result in a $\mathrm{Al}^{3+}$-induced inhibition of root cell elongation ${ }^{7,8}$.

Plant hormones are involved in plant adaptation to environmental stresses, including $\mathrm{Al}^{3+}$ stress $^{9-11}$. The involvement of auxin in a plant's response to heavy metal toxicity has been investigated in recent years. For example, cadmium toxicity altered IAA distribution by increasing the activity of IAA oxidase in roots of Medicago truncatula seedlings ${ }^{12}$ and disturbed auxin homeostasis by affecting the distribution, metabolism, and transport of auxin in Arabidopsis seedlings ${ }^{13,14}$. Additionally, auxin transport via AUXIN RESISTANT 1 (AUX1) has

${ }^{1}$ School of Agriculture and Biology, Shanghai Jiao Tong University, Shanghai 200240, P. R. China. ${ }^{2}$ Department of Plant Biology and Pathology, Rutgers, The State University of New Jersey, New Jersey, NJ 08901, USA. ${ }^{3}$ Instrumental Analysis Centre of Shanghai Jiao Tong University, Shanghai Jiao Tong University, Shanghai 200240, P. R. China. ${ }^{4}$ Key Laboratory of Urban Agriculture (South), Ministry of Agriculture, Shanghai 201101, China. Correspondence and requests for materials should be addressed to P.Z. (email: pengzhou0063@sjtu.edu.cn) orY.A. (email: anyuan@ sjtu.edu.cn) 

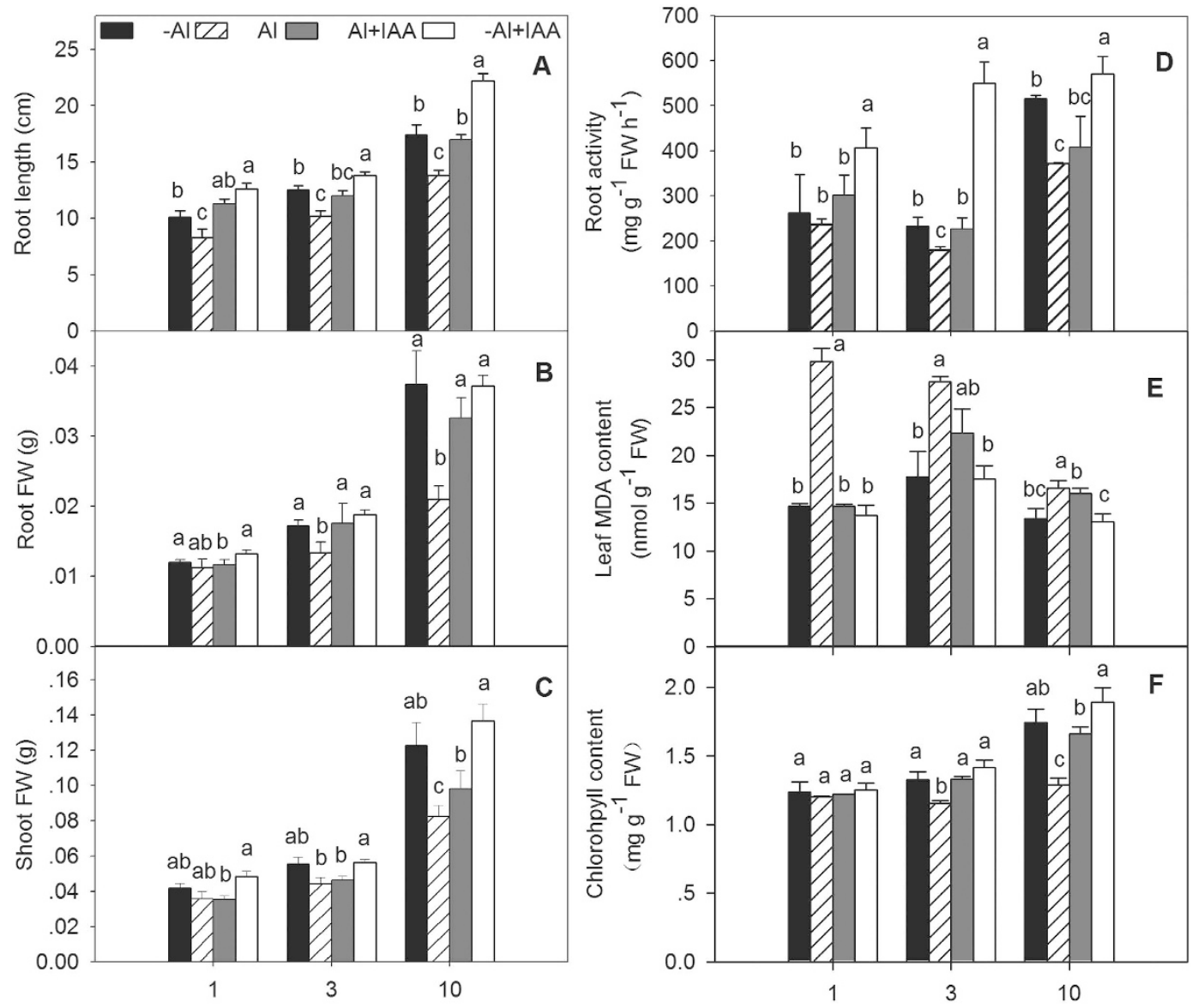

Days of $\mathrm{Al}^{3+}$ treatment

Figure 1. Root length (A), shoot (B), root (C) fresh weight (FW), root activity (D), leaf MDA content (E), and total chlorophyll content (F) in alfalfa seedlings grown for 1,3 and 10 days on $1 / 2$-strength Hoagland's medium ( $\mathrm{pH} 4.5)$ with treatments of no aluminium (-Al), aluminium stress ( $\mathrm{Al})\left(100 \mu \mathrm{M} \mathrm{AlCl}_{3}\right)$, aluminium with additional IAA $(\mathrm{Al}+\mathrm{IAA})\left(100 \mu \mathrm{M} \mathrm{AlCl}_{3}+\mathrm{IAA}\right)$ and $-\mathrm{Al}$ with additional IAA $(-\mathrm{Al}+\mathrm{IAA})$. Data are means $\pm \mathrm{SE}$ of three replicates. Bars with different letters indicate a significant difference at $P<0.05$ (least significant difference test).

been shown to play a positive role in plant tolerance to arsenite stress by influencing reactive oxygen species (ROS)-mediated signalling pathways ${ }^{15}$. Finally, copper $\left(\mathrm{Cu}^{2+}\right)$ treatments modulated auxin redistribution via regulation of PINFORMED1 (PIN1) in Arabidopsis roots, and exogenous application of auxin reduced the toxic effect of $\mathrm{Cu}^{2+}$ on sunflower (Helianthus annuus), leading to an increase in root length and root hair formation ${ }^{16,17}$. However, limited information is available on the roles that auxin plays in plant responses to $\mathrm{Al}^{3+}$ stress.

Alfalfa (Medicago sativa L.) is an important legume and is used as a forage crop worldwide, but aluminium toxicity is a major factor limiting alfalfa production in soils with low $\mathrm{pH}^{18,19}$. Understanding the mechanisms underlying IAA regulation of alfalfa's response to $\mathrm{Al}^{3+}$ is important for developing $\mathrm{Al}^{3+}$-tolerant germplasm through genetic modification or molecular breeding. Our previous study showed that IAA concentrations in apical buds and root tips of $\mathrm{Al}^{3+}$-stressed seedlings decreased in a short period (1-3 d) of $\mathrm{Al}^{3+}$ stress $^{20}$, which may reduce the growth of alfalfa seedlings under $\mathrm{Al}^{3+}$ stress. In the present study, we aimed to further investigate the following questions: (1) What was the reason of IAA accumulation decrease in the $\mathrm{Al}^{3+}$-stressed root tips? (2) What was the effect of $\mathrm{Al}^{3+}$ stress on cell structure and IAA distribution in root tips? (3) Was there any effect of IAA on the cell structure formation of the $\mathrm{Al}^{3+}$-stressed root tips?

\section{Results}

IAA alleviated $\mathrm{Al}^{3+}$-induced plant growth. The primary $\mathrm{Al}^{3+}$ toxicity in plants is the inhibition of root growth. When alfalfa seedlings were exposed to varying concentrations of $\mathrm{AlCl}_{3}(0,50,100,200$ or $300 \mu \mathrm{M})$ for $48 \mathrm{~h}$, the inhibition of roots elongation was positively dependent on $\mathrm{AlCl}_{3}$ concentrations, in which the higher decline rate of relative root growth was in the $\mathrm{Al}^{3+}$ concentration of $100 \mu \mathrm{M}$ (Supplemental Fig. 1). Root length of alfalfa exposed to $100 \mu \mathrm{M} \mathrm{AlCl}_{3}$ was significantly reduced by $17-21 \%$ relative to plants without $\mathrm{Al}^{3+}$ treatments (-Al, control) from 1 to $10 \mathrm{~d}$ of treatment (Fig. 1A). Root fresh weight (Fig. 1B), shoot fresh weight (Fig. 1C), root activity (Fig. 1D) and total chlorophyll content (Fig. 1F) were significantly decreased after $3 \mathrm{~d}^{\text {of }} \mathrm{Al}^{3+}$ treatment and were 56.1, 32.9, 27.9 and $26.2 \%$ lower than those in control plants at $10 \mathrm{~d}$ of $\mathrm{Al}^{3+}$ treatment, respectively. The 

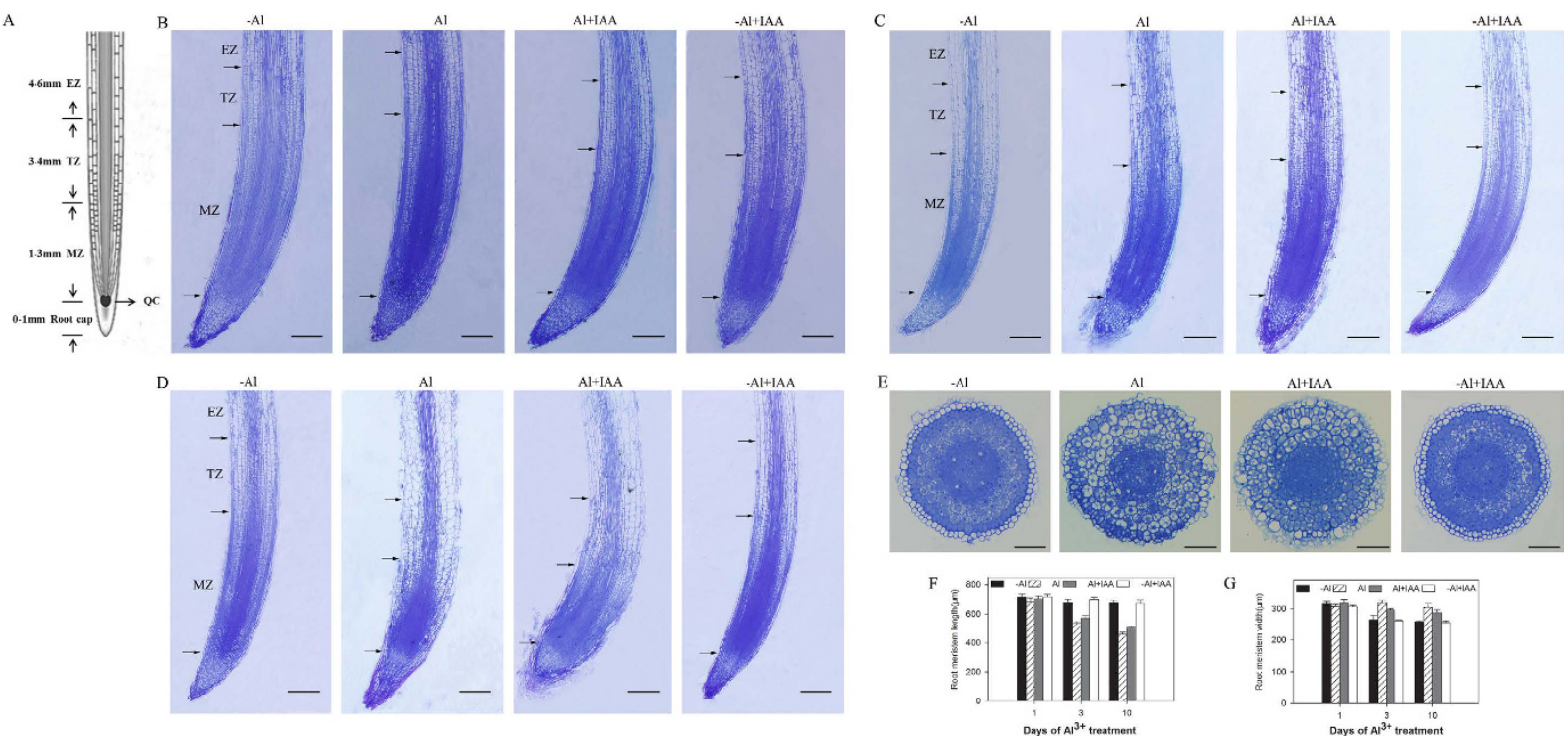

Figure 2. Images of root tips $(0-6 \mathrm{~mm})$ in the middle longitudinal section of alfalfa seedlings grown for 1,3 and 10 days on $1 / 2$-strength Hoagland's medium ( $\mathrm{pH} \mathrm{4.5)}$ with treatments of no aluminium (-Al), aluminium stress (Al) $\left.(100 \mu \mathrm{M} \mathrm{AlCl})_{3}\right)$, aluminium with additional IAA (Al + IAA) $\left(100 \mu \mathrm{M} \mathrm{AlCl}{ }_{3}+\mathrm{IAA}\right)$ and -Al with additional IAA (-Al + IAA). Root tip (A) was divided into the root cap, the transition zone (TZ), the meristematic zone (MZ) and the elongation zone (EZ) and is indicated by arrowheads. The quiescent centre was marked as QC. A cross-section was cut in the middle of the meristematic zone (E) on day 10. Scale bars in longitudinal sections indicate $100 \mu \mathrm{m}$; in cross-sections, they indicate $50 \mu \mathrm{m}$. The length $(\mathbf{F})$ and width $(\mathbf{G})$ of the root meristems were measured. Data are means $\pm S E$ of three replicates. Bars with different letters indicate a significant difference at $P<0.05$ (least significant difference test).

MDA content in leaves of $\mathrm{Al}^{3+}$-stressed plants (Fig. 1E) was significantly increased compared to control plants during the experimental periods.

Compared with $\mathrm{Al}^{3+}$ treatment alone, the addition of IAA (Al + IAA) markedly increased root length (Fig. 1A), root fresh weight (Fig. 1B), shoot fresh weight (Fig. 1C), and total chlorophyll content (Fig. 1F) after $10 \mathrm{~d}$ of the experiment. The MDA content in leaves treated with Al+ IAA decreased to levels near those of the control plants (-Al) (Fig. 1E).

IAA alleviated $\mathrm{Al}^{3+}$-induced damage of root tip structure. Root tips mainly contain four regions: the root cap (0-1 mm from the tip), meristematic zone (MZ 1-3 mm), transition zone (TZ 3-4 $\mathrm{mm}$ ) and elongation zone (EZ 4-6 mm) (Fig. 2A). Compared with the control, $\mathrm{Al}^{3+}$ treatments decreased the root meristem length at 1,3 and $10 \mathrm{~d}$ (Fig. 2B-D,F) and enhanced the root meristem width at 3 and $10 \mathrm{~d}$ (Fig. 2G). The tissue structure in the whole root tip was damaged by the addition of $\mathrm{Al}^{3+}$. The cell arrangement was also disordered, and the cell shape was distorted from a rectangle into an irregular shape in the epidermis and cortex and even in the stele of the TZ and EZ (Fig. 2C,D). The cell length enlarged in the cortex in all root tip zones, the epidermal cells in the root cap detached, and the root tips became obtuse (Fig. 2D). Compared with the control (-Al) and based on the cross-section in the middle of the MZ (Fig. 2E), the epidermal cell was seriously damaged, the cell and vacuole enlarged, the intercellular space diminished, the thickness of the cortex increased, and the diameter of the stele decreased. However, the addition of IAA $(\mathrm{Al}+\mathrm{IAA})$ protected the tissue structure of the $\mathrm{Al}^{3+}$-stressed root tip in which the cell arrangement, cell shape and cell length as well as the thickness of the cortex were close to those of the control plant (no $\mathrm{Al}^{3+}$ addition), and the meristem length increased compared with $\mathrm{Al}^{3+}$ treatment alone (Fig. 2A-F).

$\mathrm{Al}^{3+}$ altered IAA distribution in plants. To explore the IAA distribution in alfalfa root tips, the immunohistochemical method of staining with antibodies was used in this study. In the control (-Al) and - Al + IAA treatments, a high intensity of homogeneous fluorescence signals was detected as a continuous dotted line in the epidermis, cortex (close to the endodermis), endodermis and stele of the TZ and distal MZ (Fig. 3A,B), whereas weak signals was detected in the EZ during the 10-d experimental period (Fig. $3 \mathrm{C}$ ). However, in the $\mathrm{Al}^{3+}$ treat- $^{-}$ ment alone, the distribution of fluorescence signals in root tips was disturbed; the dotted line characterizing fluorescence signals disappeared (Fig. 3B,C). Discontinuous fluorescence signals were detected in the epidermis, cortex (close to the endodermis), endodermis, and stele of the $\mathrm{TZ}$ and distal MZ. On the other hand, a higher intensity of fluorescence signals was detected in all tissues of the apical MZ compared with the control (-Al) treatment after $10 \mathrm{~d}$ of $\mathrm{Al}^{3+}$ treatment (Fig. 3B,C), which means that the distribution of IAA was altered in root tips. Higher IAA accumulation in the apical MZ and lower IAA accumulation in the TZ compared with the control (-Al) treatment indicated that IAA transportation in root tips was inhibited. 


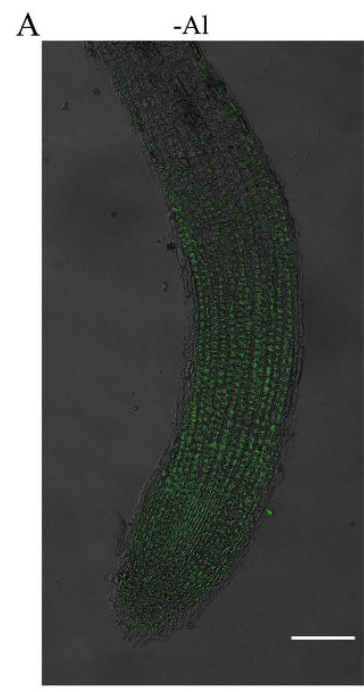

B

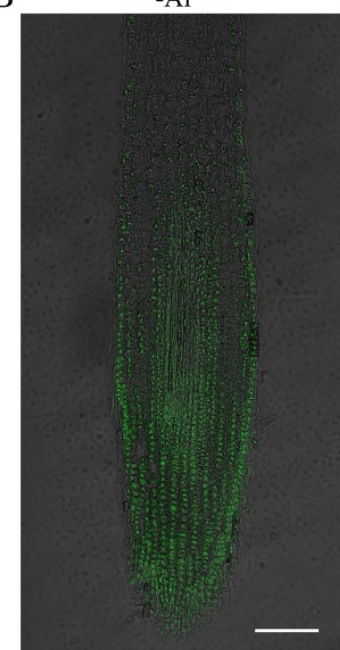

C

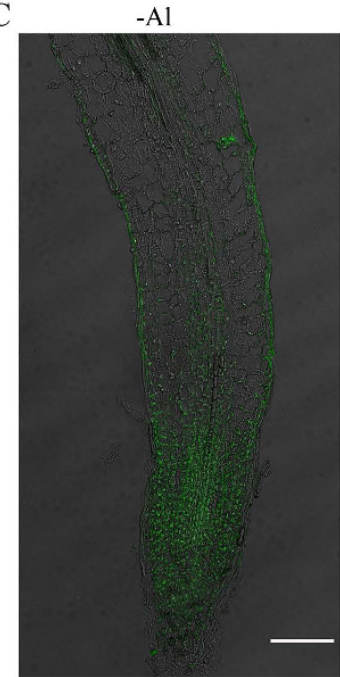

$\mathrm{Al}$

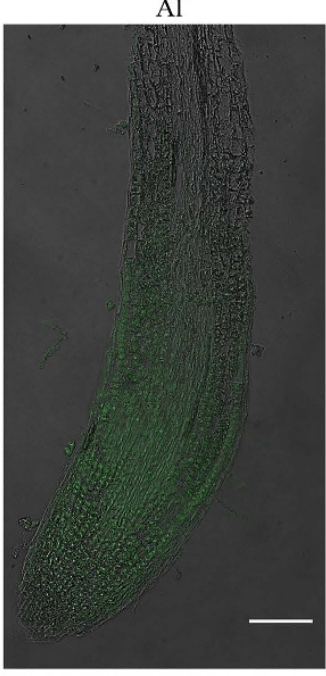

Al

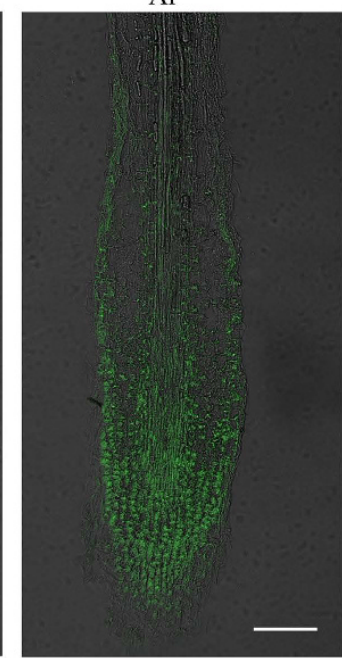

Al

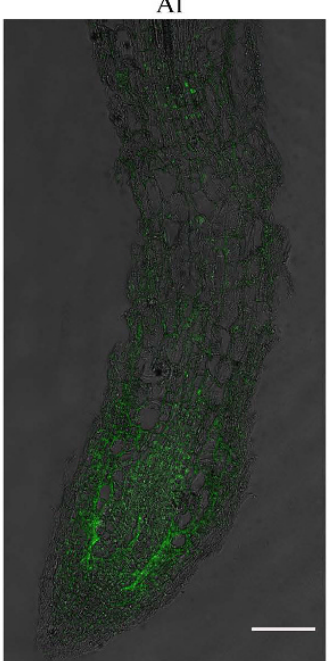

$\mathrm{Al}+\mathrm{IAA}$

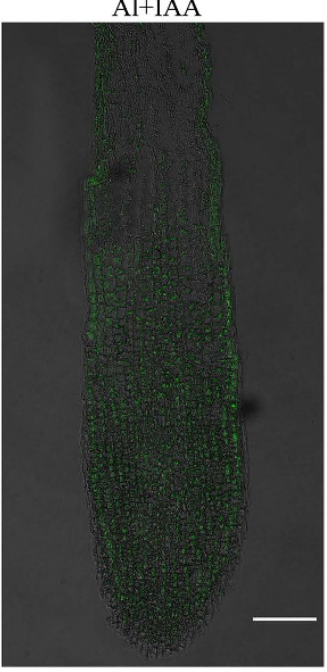

Al+IAA

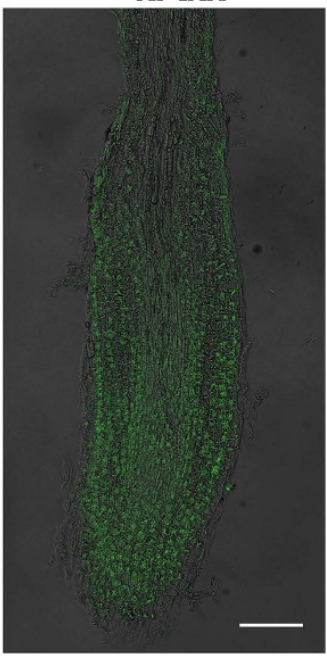

Al+IAA

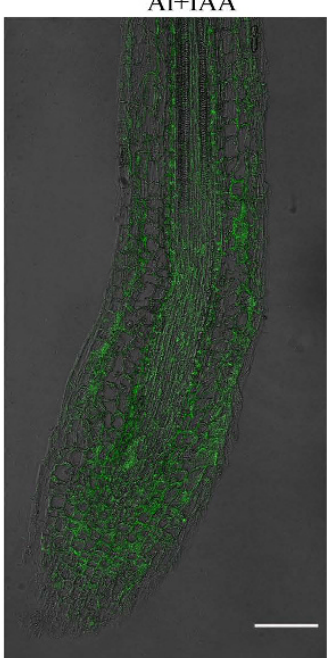

$-\mathrm{Al}+\mathrm{IAA}$

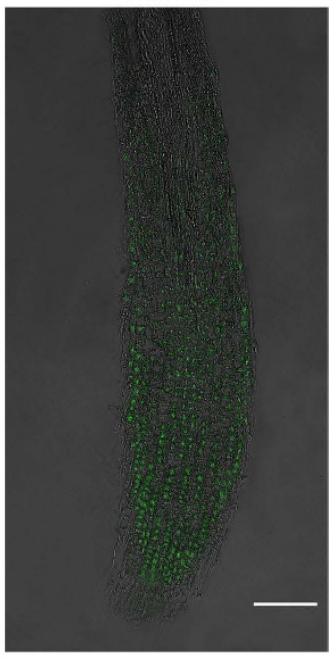

-Al+IAA

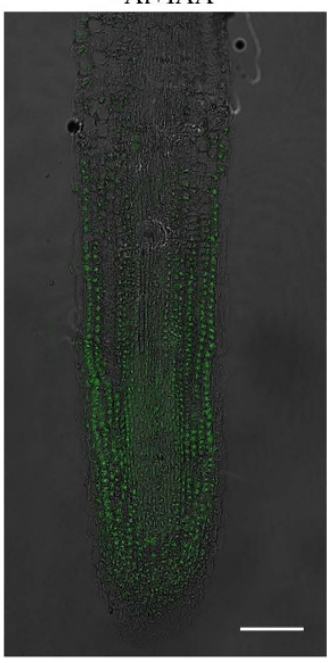

$-\mathrm{Al}+\mathrm{IAA}$

Figure 3. Immunolocalization of IAA in the middle longitudinal section of alfalfa seedlings grown for $1,3$ and 10 days on $1 / 2$-strength Hoagland's medium ( $\mathrm{pH} 4.5)$ with treatments of no aluminium (-Al), aluminium stress $(\mathrm{Al})(100 \mu \mathrm{M} \mathrm{AlCl})_{3}$, aluminium with additional IAA (Al + IAA) $\left(100 \mu \mathrm{M} \mathrm{AlCl}_{3}+\mathrm{IAA}\right)$ and -Al with additional IAA (-Al + IAA). Scale bars in each image indicate $100 \mu \mathrm{m}$.

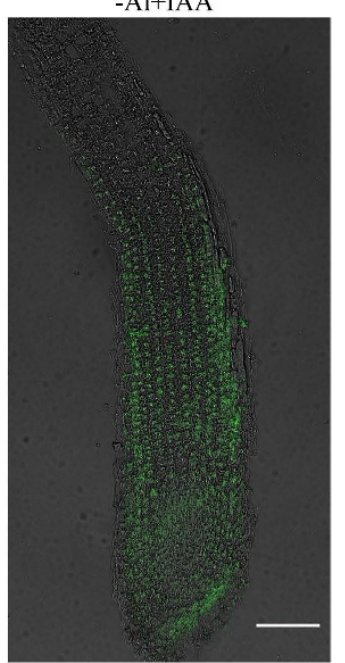



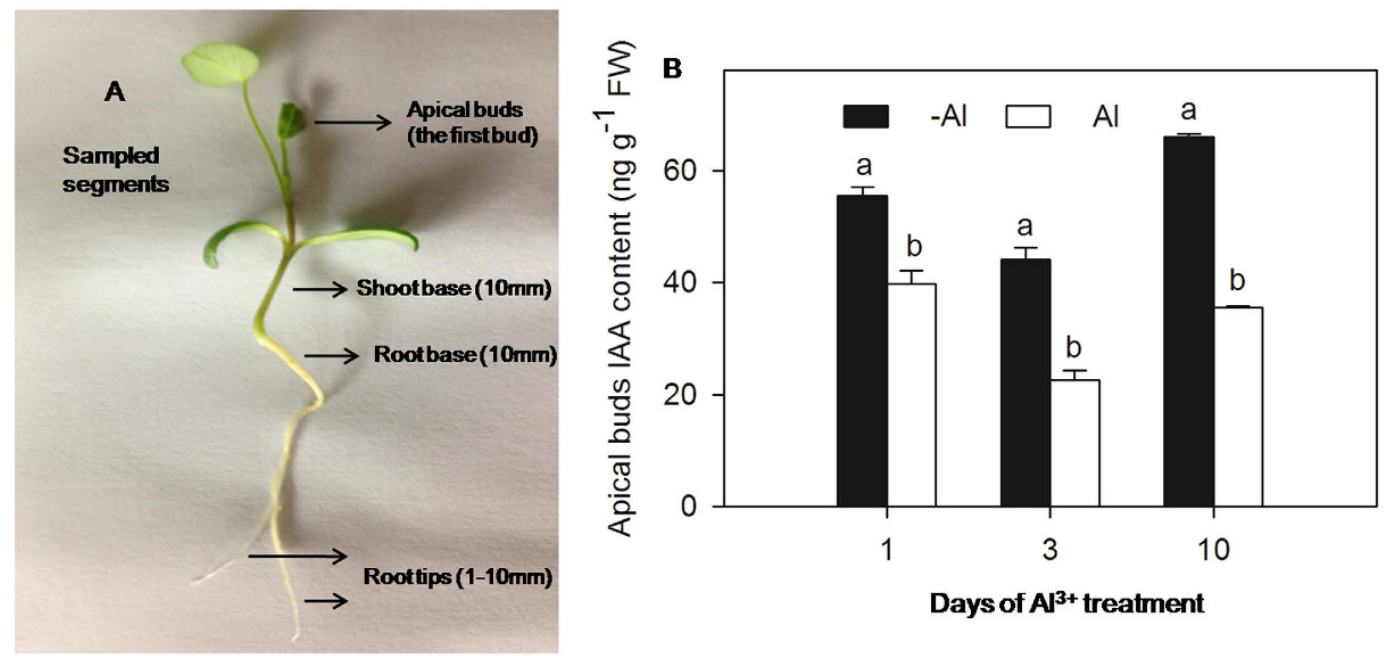

Figure 4. Sampled segments are shown in (A); IAA concentrations in apical buds of alfalfa seedlings grown

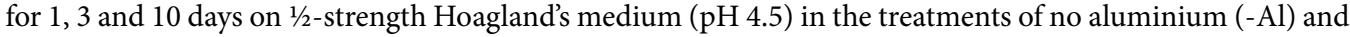
aluminium stress $(\mathrm{Al})\left(100 \mu \mathrm{M} \mathrm{AlCl}_{3}\right)(\mathbf{B})$. Data are means \pm SE of three replicates. Bars with different letters indicate a significant difference at $P<0.05$ (least significant difference test).

In the combined treatment of $\mathrm{Al}^{3+}$ with IAA $(\mathrm{Al}+\mathrm{IAA})$, the IAA signals were less disturbed by $\mathrm{Al}^{3+}$ stress (Fig. 3A-C); the dotted lines of fluorescence signals were clearer and more continuous than in $\mathrm{Al}^{3+}$ treatment alone after $3 \mathrm{~d}$ of $\mathrm{Al}^{3+}$ treatment (Fig. 3A,B). The distributional intensity of fluorescence signals in the whole root tip was also close to that of the control plant. The IAA signals in the epidermis, cortex and stele of the TZ were increased compared with the $\mathrm{Al}^{3+}(\mathrm{Al})$ treatment, indicating that exogenous application of IAA could compensate for the lack of IAA in the $\mathrm{TZ}$ under $\mathrm{Al}^{3+}(\mathrm{Al})$ treatment. Either the primary antibody or the secondary antibody was omitted during the complete procedure, and no signals were observed in the two antibody breeding procedures (Supplementary Fig. 2).

To evaluate the mechanism by which exogenous application of IAA alleviates $\mathrm{Al}^{3+}$ toxicity, IAA concentration in different parts of the plant was measured. Sampled segments are shown in Fig. 4A. When alfalfa was exposed to $100 \mu \mathrm{M} \mathrm{AlCl}_{3}$, IAA concentrations in apical buds (Fig. 4B) and root tips at 1, 3, and $10 \mathrm{~d}$ as well as in the shoot base at 3 and $10 \mathrm{~d}$ were significantly reduced compared to control plants (Table 1 ). However, the degree of reduction in apical buds (25-50\%) was lower than in root tips (75-90\%) (Table 1). IAA concentrations in the root base were significantly higher in both the $\mathrm{Al}^{3+}$ treatment and $\mathrm{Al}^{3+}$ with IAA treatment $(\mathrm{Al}+\mathrm{IAA})$ compared to both the treatment without $\mathrm{Al}^{3+}(-\mathrm{Al})$ and $-\mathrm{Al}^{3+}$ with IAA treatment $(-\mathrm{Al}+\mathrm{IAA})$, respectively, after $3 \mathrm{~d}$ (Table 1).

Compared to $\mathrm{Al}^{3+}$ treatment alone, $\mathrm{Al}+\mathrm{IAA}$ significantly increased (by 40-140\%) IAA concentrations in the shoot base throughout the experimental period; however, the increased IAA concentration in root tips reached a significant level only at $1 \mathrm{~d}$ of $\mathrm{Al}+\mathrm{IAA}$ treatment (Table 1$)$. In contrast to the treatment without $\mathrm{Al}^{3+}(-\mathrm{Al})$, $-\mathrm{Al}+\mathrm{IAA}$ induced an increase in IAA concentrations in both the shoot base and root tips, by $20-88 \%$ and $25-96 \%$, respectively, throughout the experimental period (Table 1). After exogenous application of IAA, the degree of increase in IAA in root tips was lower in the plants treated with $\mathrm{Al}^{3+}$ than in those without $\mathrm{Al}^{3+}$. In addition, regardless of IAA treatment, the ratio of IAA concentrations between root tips and shoot base was lower in the presence of $\mathrm{Al}^{3+}$ than without $\mathrm{Al}^{3+}$ throughout the experimental period (Table 1).

To further explore the effect of $\mathrm{Al}^{3+}$ on IAA distribution in the plant, apical buds that were a primary site for IAA synthesis were removed $24 \mathrm{~h}$ before $\mathrm{Al}^{3+}$ treatment; this was done to eliminate the effect of endogenous IAA synthesis. Compared with plants with intact apical buds, the IAA concentration in root tips was significantly decreased in plants without apical buds in both the - $\mathrm{Al}$ and $\mathrm{Al}$ treatment, by $89.8 \%$ and $87.6 \%$, respectively (Fig. 5). In bud-removed plants, exogenous application of IAA significantly increased IAA concentrations in root tips in both - $\mathrm{Al}+\mathrm{IAA}$ and $\mathrm{Al}+\mathrm{IAA}$ treatments, 25 -fold and 10-fold higher than those in - $\mathrm{Al}^{3+}$ and $\mathrm{Al}^{3+}$ treatments, respectively (Fig. 5). The degree of increase was lower in the $\mathrm{Al}^{3+}$ treatment than in the treatment without $\mathrm{Al}^{3+}$.

Magnesium $\left(\mathrm{Mg}^{2+}\right)$ and zinc $\left(\mathrm{Zn}^{2+}\right)$ alleviated $\mathrm{Al}^{3+}$-induced inhibition of root elongation by increased IAA accumulation in root tips. Compared with $\mathrm{Al}^{3+}$ treatment alone, the addition of $\mathrm{Mg}^{2+}$ (Fig. 6A) and $\mathrm{Zn}^{2+}$ (Fig. 6B) to the $\mathrm{Al}^{3+}$ treatment significantly increased root length, which reached the same level as the control (-Al) after $1 \mathrm{~d}$ of treatment. The addition of $25 \mu \mathrm{M}$ and $50 \mu \mathrm{M} \mathrm{Mg}^{2+}$ with excess $\mathrm{Al}^{3+}$ for $1 \mathrm{~d}$ also significantly increased IAA concentrations in the root tips 9.2-fold and 9.5-fold, respectively, in comparison with $\mathrm{Al}^{3+}$ treatment (Fig. $6 \mathrm{C}$ ). The addition of $25 \mu \mathrm{M}$ or $50 \mu \mathrm{M} \mathrm{Zn}^{2+}$ significantly increased IAA concentrations in the root tips by 56.73 and $340 \%$, respectively (Fig. 6D).

IAA decreased $\mathrm{Al}^{3+}$-induced callose production in plants. Compared to the treatment without $\mathrm{Al}^{3+}$ (-Al), callose content in root tips increased by $10.9,20.4$ and $27.0 \%$ at 1,3 and $10 \mathrm{~d}$ of $\mathrm{Al}^{3+}$ treatment, respectively (Fig. 7A). Callose content in shoots under $\mathrm{Al}^{3+}$ treatment also increased by $45.9 \%$ at $10 \mathrm{~d}$ but showed no 


\begin{tabular}{|c|c|c|c|c|c|c|c|c|c|c|c|c|}
\hline \multirow[b]{2}{*}{ Treatments } & \multicolumn{4}{|c|}{ 1d } & \multicolumn{4}{|c|}{$3 d$} & \multicolumn{4}{|c|}{ 10d } \\
\hline & Root tips & $\begin{array}{l}\text { Root } \\
\text { base }\end{array}$ & Shoot base & $\begin{array}{c}\text { Root tips/ } \\
\text { shoot } \\
\text { base }^{*}\end{array}$ & Root tips & Root base & Shoot base & \begin{tabular}{|c|} 
Root tips/ \\
shoot \\
base $^{*}$
\end{tabular} & Root tips & Root base & Shoot base & $\begin{array}{c}\text { Root tips/ } \\
\text { shoot } \\
\text { base }^{*}\end{array}$ \\
\hline$-\mathrm{Al}$ & $1.276 \pm 0.215 \mathrm{~b}$ & 1 & $12.81 \pm 1.784 \mathrm{~b}$ & 9.961 & $2.397 \pm 0.407 \mathrm{a}$ & $3.672 \pm 0.481 \mathrm{~b}$ & $34.49 \pm 1.230 \mathrm{~b}$ & 6.950 & $1.193 \pm 0.131 b$ & $3.435 \pm 0.420 \mathrm{~b}$ & $23.43 \pm 0.504 \mathrm{~b}$ & 5.092 \\
\hline $\mathrm{Al}$ & $0.185 \pm 0.044 c$ & 1 & $11.93 \pm 1.279 \mathrm{~b}$ & 1.551 & $0.219 \pm 0.058 \mathrm{~b}$ & $6.079 \pm 0.687 \mathrm{a}$ & $17.79 \pm 2.557 \mathrm{c}$ & 1.231 & $0.315 \pm 0.038 \mathrm{c}$ & $5.117 \pm 0.507 \mathrm{a}$ & $13.53 \pm 1.890 \mathrm{~d}$ & 2.328 \\
\hline $\mathrm{Al}+\mathrm{IAA}$ & $0.772 \pm 0.189 b c$ & 1 & $22.75 \pm 0.787 \mathrm{a}$ & 3.393 & $0.348 \pm 0.069 \mathrm{~b}$ & $5.491 \pm 0.001 \mathrm{a}$ & $42.83 \pm 3.435 \mathrm{a}$ & 0.813 & $0.562 \pm 0.199 \mathrm{c}$ & $6.084 \pm 0.615 a$ & $19.10 \pm 0.748 c$ & 2.942 \\
\hline$-\mathrm{Al}+\mathrm{IAA}$ & $2.506 \pm 0.405 a$ & 1 & $24.13 \pm 2.052 \mathrm{a}$ & 10.385 & $2.996 \pm 0.119 \mathrm{a}$ & $2.941 \pm 0.318 \mathrm{~b}$ & $43.82 \pm 3.155 \mathrm{a}$ & 6.837 & $1.721 \pm 0.184 \mathrm{a}$ & $4.905 \pm 0.009 \mathrm{ab}$ & $27.91 \pm 0.491 \mathrm{a}$ & 6.166 \\
\hline
\end{tabular}

Table 1. IAA concentrations in root tips, root base and shoot base, and $\mathrm{IAA}_{[\text {root tips] }} / \mathrm{IAA}_{\text {[shoot base] }}$ radio in alfalfa seedlings grown for 1,3 and 10 days on $1 / 2$-strength Hoagland's medium $(\mathrm{pH} 4.5)$ with treatments of no Aluminum(-Al), Aluminum stress (Al) $\left(100 \mu \mathrm{M} \mathrm{AlCl}_{3}\right)$, Aluminum with additional IAA (Al+ IAA) $\left(100 \mu \mathrm{M} \mathrm{AlCl}_{3}+\mathrm{IAA}\right)$ and $-\mathrm{Al}$ with additional IAA(-Al + IAA). Data are means $\pm \mathrm{SE}$ of three replicates. Columns with different letters indicate a significant difference at $P<0.05$ (least significant difference test). *Root tips/shoot base is the radio of $100 \cdot \mathrm{IAA}_{\text {[root tips] }} / \mathrm{IAA}_{\text {[shoot base] }}$.

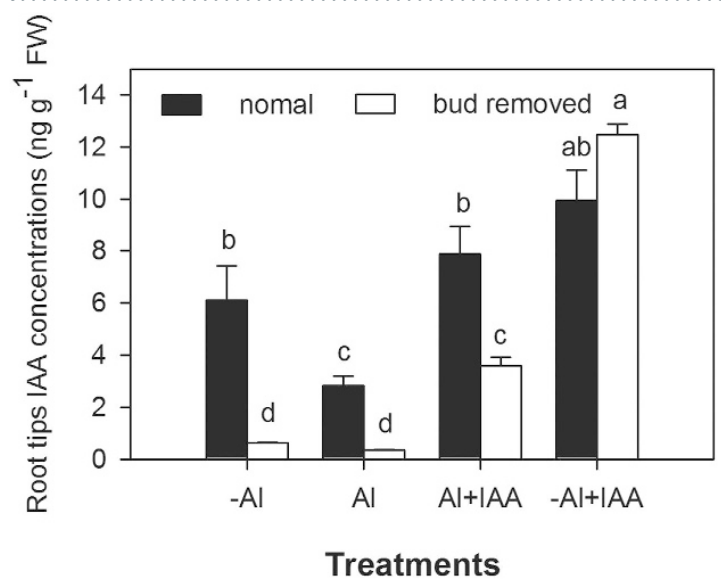

Figure 5. IAA concentrations in root tips $(0-10 \mathrm{~mm})$ of alfalfa seedlings (normal or apical bud removed) grown for $24 \mathrm{~h}$ on $1 / 2$-strength Hoagland's medium ( $\mathrm{pH} 4.5$ ) with treatments of no aluminium (-Al), aluminium stress $\left.(\mathrm{Al})(100 \mu \mathrm{M} \mathrm{AlCl})_{3}\right)$, aluminium with additional IAA (Al+IAA) $\left(100 \mu \mathrm{M} \mathrm{AlCl}{ }_{3}+\mathrm{IAA}\right)$ and -Al with additional IAA (-Al + IAA). Data are means $\pm S E$ of three replicates. Bars with different letters indicate a significant difference at $P<0.05$ (least significant difference test).

significant difference from the content under - Al treatment at $3 \mathrm{~d}$ (Fig. 7B). This finding suggests that shoot callose formation was slower than root callose formation under $\mathrm{Al}^{3+}$ stress. Compared to $\mathrm{Al}^{3+}$ treatment, callose content reduction was only $9.1 \%$ in root tips and $17.2 \%$ in shoots in the $\mathrm{Al}+\mathrm{IAA}$ treatment throughout the experimental period (Fig. 7).

$\mathrm{Al}^{3+}$ up-regulated expression levels of IAA transport related genes. The relative transcription levels of $A U X 1$ in root tips were significantly up-regulated by $\mathrm{Al}^{3+}$ treatment by $60.5,52.1$ and $30.1 \%$ at 1,3 , and $10 \mathrm{~d}$ of treatment, respectively (Fig. 8A). The relative expression levels of PIN2 in $\mathrm{Al}^{3+}$ treatment were also significantly up-regulated by $114.1,52.3$ and $7.7 \%$ at 1,3 , and $10 \mathrm{~d}$, respectively (Fig. $8 \mathrm{C}$ ), whereas the expression levels of PIN1 did not show a significant increase within the first $3 \mathrm{~d}$ but exhibited a significant increase at $10 \mathrm{~d}$ (Fig. 8B). The relative transcription levels of the three genes were all up-regulated after exogenous application of IAA in both $-\mathrm{Al}+\mathrm{IAA}$ and $\mathrm{Al}+\mathrm{IAA}$ treatments compared with - $\mathrm{Al}$ treatment, but there was no significant difference in the expression level of the three genes among the treatments of - $\mathrm{Al}+\mathrm{IAA}, \mathrm{Al}+\mathrm{IAA}$ and $\mathrm{Al}$ (Fig. 8A-C).

\section{Discussion}

$\mathrm{Al}^{3+}$ inhibition of IAA synthesis in apical buds. Various environmental and endogenous signals can be integrated into changes of auxin distribution through their effects on local auxin biosynthesis ${ }^{10,21}$. When alfalfa was exposed to $\mathrm{Al}^{3+}$-stressed conditions, IAA concentrations in apical buds and root tips were significantly decreased; the IAA concentrations in root tips in both - $\mathrm{Al}$ and $\mathrm{Al}$ treatments decreased to a very low level after the apical buds were removed. These results indicate that the synthesis of IAA is mainly in apical buds and strongly decreased by $\mathrm{Al}^{3+}$ stress, which leads to the reduction of IAA concentration in root tips.

$\mathrm{Mg}^{2+}$ is an important cofactor of phenylpyruvate decarboxylase, which is involved in the biosynthesis of $\mathrm{IAA}^{22} . \mathrm{Zn}^{2+}$ is necessary for the formation of IAA from tryptophan, one of the essential ingredients for IAA synthesis, and its concentrations indirectly affect the IAA content in plants ${ }^{23}$. The two nutrients are also extremely important for maintaining membrane function, cell extension and antioxidant enzyme activities ${ }^{24}$. $\mathrm{Al}^{3+}$ stress interfered with uptake or transport of nutrients and caused a decrease of $\mathrm{Mg}$ content in plant roots of maize (Zea 

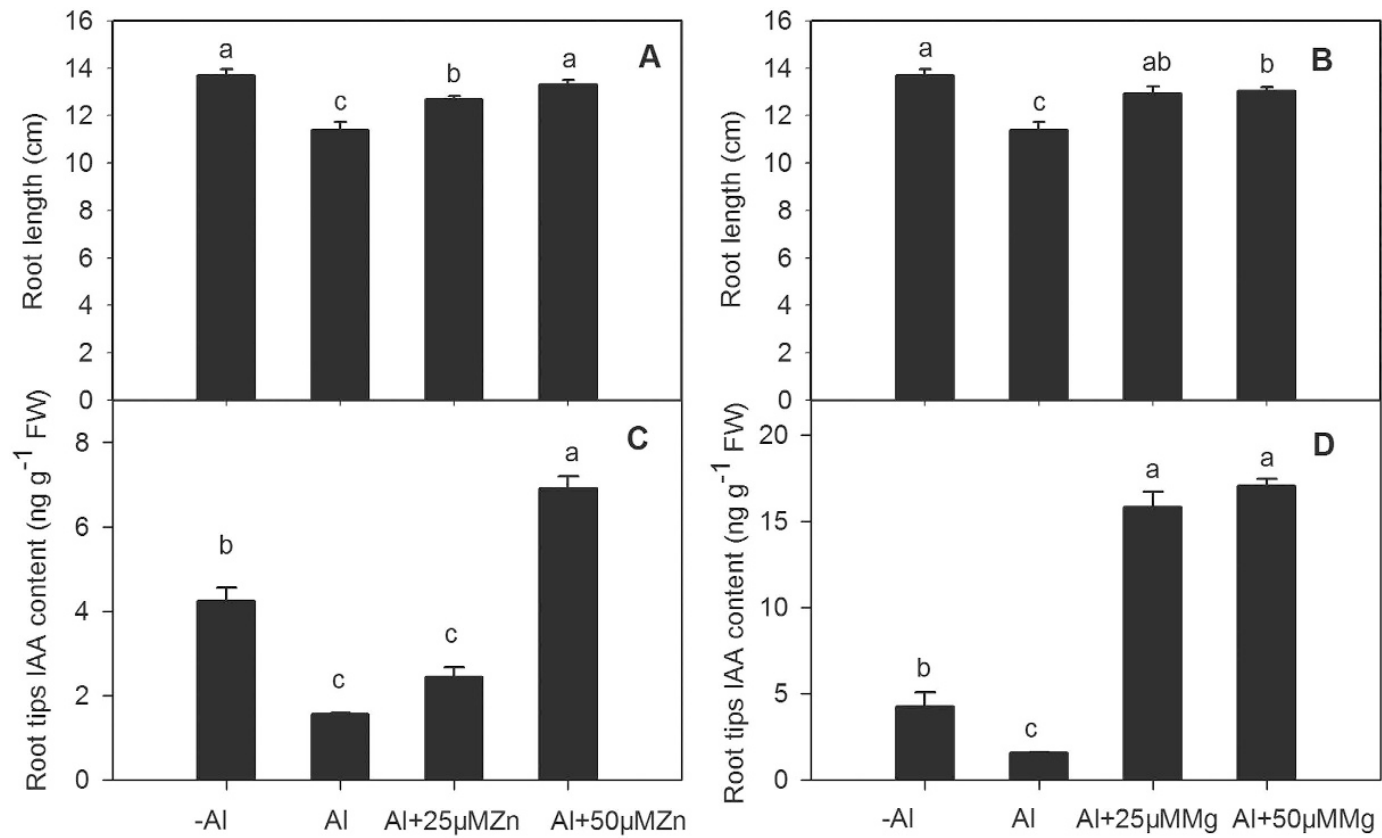

\section{Treatments}

Figure 6. Root length and IAA concentrations in root tips $(0-10 \mathrm{~mm})$ of alfalfa seedlings grown for $24 \mathrm{~h}$ on $1 / 2$-strength Hoagland's medium ( $\mathrm{pH} 4.5)$ with treatments of no aluminium (-Al), aluminium stress ( $\mathrm{Al}$ ) $\left(100 \mu \mathrm{M} \mathrm{AlCl}_{3}\right)$, aluminium together with $25 \mu \mathrm{M} \mathrm{Zn}{ }^{2+}(\mathrm{Al}+25 \mu \mathrm{M} \mathrm{Zn})$, aluminium together with $50 \mu \mathrm{M} \mathrm{Zn}{ }^{2+}$ $(\mathrm{Al}+50 \mu \mathrm{M} \mathrm{Zn})(\mathrm{A}, \mathrm{C})$, aluminium together with $25 \mu \mathrm{M} \mathrm{Mg}^{2+}(\mathrm{Al}+25 \mu \mathrm{M} \mathrm{Mg})$ and aluminium together with $50 \mu \mathrm{M} \mathrm{Mg}^{2+}(\mathrm{Al}+50 \mu \mathrm{M} \mathrm{Mg})(\mathbf{B}, \mathrm{D})$. Data are means $\pm \mathrm{SE}$ of three replicates. Bars with different letters indicate a significant difference at $P<0.05$ (least significant difference test).

mays), rice (Oryza.sativa), wheat (Triticum aestivum) and alfalfa ${ }^{6,24,25}$. Exogenous application of $\mathrm{Mg}^{2+}$ in culture medium could alleviate $\mathrm{Al}^{3+}$ toxicity in many plant species ${ }^{26}$; meanwhile, up-regulation of $\mathrm{Mg}^{2+}$ transporter genes, particularly those for high-affinity $\mathrm{Mg}^{2+}$ transporters, could contribute to amelioration of $\mathrm{Al}^{3+}$ toxicity by enhancing $\mathrm{Mg}^{2+}$ uptake in Arabidopsis ${ }^{27}$. The proposed mechanisms for $\mathrm{Al}^{3+}$ toxicity alleviation by $\mathrm{Mg}^{2+}$ ions include (i) increase of organic acid synthesis and exudation; (ii) reduction in $\mathrm{Al}^{3+}$ saturation at the apoplastic exchange sites; and (iii) decrease of $\mathrm{Al}^{3+}$ activity at the root cell plasma membrane surface, and restored plasma membrane $\mathrm{H}^{+}$-ATPase activity ${ }^{26,28}$. In present study, the absence of $\mathrm{Mg}^{2+}$ and $\mathrm{Zn}^{2+}$ resulted in a significant decrease in IAA concentration in root tips of $\mathrm{Al}^{3+}$-stressed alfalfa. On the other hand, application of $\mathrm{Mg}^{2+}$ and $\mathrm{Zn}^{2+}$ significantly increased IAA concentrations in root tips and also enhanced root growth, indicating that $\mathrm{Al}^{3+}$-induced deficiency of $\mathrm{Mg}^{2+}$ and $\mathrm{Zn}^{2+}$ in roots could be associated with the reduction of IAA synthesis in apical buds. The effect of $\mathrm{Mg}^{2+}$ on alleviating $\mathrm{Al}^{3+}$-induced IAA reduction in root tip was higher than $\mathrm{Zn}^{2+}$, The IAA concentrations in root tips under $\mathrm{Al}^{3+}$ stress was 6.5 -fold and 2.5 -fold higher in treatments of $25 \mu \mathrm{M}$ and $50 \mu \mathrm{M} \mathrm{Mg}^{2+}$ in comparison with treatments of $25 \mu \mathrm{M}$ and $50 \mu \mathrm{M} \mathrm{Zn}^{2+}$, respectively. The function of the $\mathrm{Mg}^{2+}$ in increasing the IAA concentration in $\mathrm{Al}^{3+}$-stressed root tip may associate with increase ${ }^{22}$ of IAA biosynthesis and decrease of $\mathrm{Al}^{3+}$ activity on the root cell plasma membrane surface reflected by a normal cell structure and a convenient array of IAA fluorescence signals in $\mathrm{Al}^{3+}$-stressed root tips after exogenous application IAA.

$\mathrm{Al}^{3+}$ inhibition of IAA transport and disruption of IAA distribution in root tip. IAA is transported from auxin-synthesized young shoot tissues via phloem to the root tip and is then redirected to the epidermis and outer cortex ${ }^{10,29}$. Inhibition of basipetal auxin flow disturbs auxin distribution in plants and causes adverse effects on root growth and morphology ${ }^{10}$. In the present study, the ratio of IAA concentration between root tip and shoot base was 2-6 times lower in the presence $\mathrm{Al}^{3+}$ than in the absence of $\mathrm{Al}^{3+}$; meanwhile, after exogenous application of IAA to plants with or without apical buds, the increased degrees of IAA accumulation in root tips were lower in the plants treated with $\mathrm{Al}^{3+}$ than in those with no $\mathrm{Al}^{3+}$. In addition, the distribution of fluorescence signals in root tips of $\mathrm{Al}^{3+}$-stressed alfalfa was disturbed; the dotted lines of fluorescence signals were not clear and were discontinuous in the endodermis, the cortex (close to the endodermis) and the stele of the TZ and distal $\mathrm{MZ}$. These two results and the phenomenon overall strongly demonstrated that $\mathrm{Al}^{3+}$ inhibited IAA transport from shoots to root tips. As a result, a higher amount of IAA accumulated in the root base, but a lower amount accumulated in root tips.

Although $\mathrm{Al}^{3+}$ stress caused a reduction of IAA concentration in the root tip, stronger IAA fluorescence signals were presented in the apical $\mathrm{MZ}$, including the quiescent centre (QC), a highly efficient operation centre of IAA polar transport ${ }^{30,31}$. As well as fewer IAA signals were observed in the $\mathrm{TZ}$ and $\mathrm{EZ} \mathrm{under} \mathrm{Al}^{3+}$ treatment. Using the isotopic tracer method, Kollmeier et al. ${ }^{7}$ found that $\mathrm{Al}^{3+}$ treatment increased auxin accumulation in 

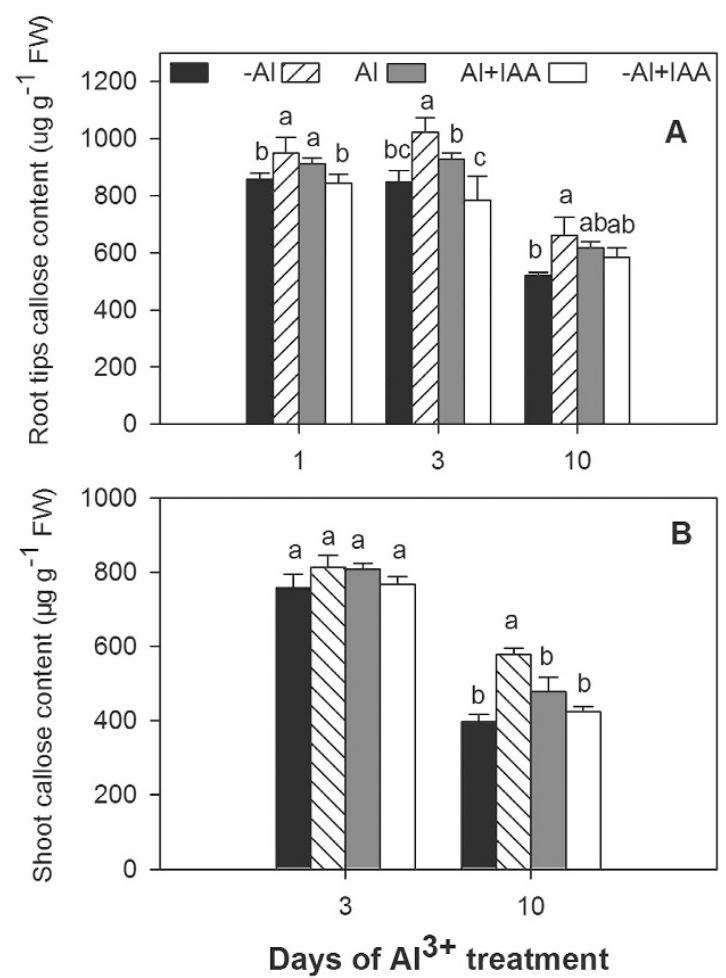

Figure 7. Callose content in root tips $(0-10 \mathrm{~mm})(\mathbf{A})$ and shoot $(\mathbf{B})$ of alfalfa seedlings grown for 1,3 and 10 days on $1 / 2$-strength Hoagland's medium ( $\mathrm{pH} 4.5$ ) with treatments of no aluminium (-Al), aluminium stress (Al) $\left(100 \mu \mathrm{M} \mathrm{AlCl}\right.$ ), aluminium with additional IAA (Al+ IAA) $\left(100 \mu \mathrm{M} \mathrm{AlCl}_{3}+\mathrm{IAA}\right)$ and -Al with additional IAA $(-\mathrm{Al}+\mathrm{IAA})$. Data are means $\pm \mathrm{SE}$ of three replicates. Bars with different letters indicate a significant difference at $P<0.05$ (least significant difference test).

the MZ and DTZ (the distal transition zone) but reduced auxin levels in the EZ of maize root tips. These results indicated that $\mathrm{Al}^{3+}$ stress decreased IAA accumulation in root tips, but the IAA distribution was unbalanced. The meristematic, transition and elongation zones determined primary root development and root growth. Appropriate concentrations of auxin in the distinct zones could promote cell division and root elongation; for example, an external supply of auxin to the EZ was able to partially overcome the inhibition of root growth in maize caused by $\mathrm{Al}^{3+}$ stress $^{7}$, but excessive auxin will reduce cell division and root elongation. Over-accumulation of IAA in the apical meristem might have a negative effect on cell division and root elongation. The reduction and imbalance of IAA accumulation in root tips of $\mathrm{Al}^{3+}$-stressed alfalfa could together influence cell division, elongation and differentiation in the distinct zones of roots; as a result, restricted root development and growth.

$\mathrm{Al}^{3+}$-induced cellular response in root tips inhibited IAA transport and root growth. High concentrations of $\mathrm{Al}^{3+}$ ions inhibited root development at the organ, tissue, and cellular levels ${ }^{32}$. The $\mathrm{Al}^{3+}$ ions were located in the epidermis and stele of $\mathrm{Al}^{3+}$-stressed roots ${ }^{20}$, which could inhibit cell division and elongation ${ }^{33,34}$, changed cell pattern $s^{35}$ in the epidermis and stele, and even damaged the epidermis and stele ${ }^{36}$. An obvious characteristic of root development under $\mathrm{Al}^{3+}$-stressed conditions was swollen and short root tips, including fibrous roots. Changes in both cell division and cell elongation could alter root tip morphology. In the present study, the diameter of the stele was decreased, while the cortex width was enlarged due to cell enlargements under $\mathrm{Al}^{3+}$ stress, which directly caused swelling of the root tip. The cell enlargement was attributed to the $\mathrm{Al}^{3+}$-induced vacuole enlargements. Vacuole enlargement might be necessary for plants to store excessive $\mathrm{Al}^{3+}$ and adapt to conditions of $\mathrm{Al}^{3+}$ stress $^{37,38}$, but this change might disturb root functions such as nutrient absorption, and reduced root growth; thus, vacuole enlargement might be an important characteristic of plant $\mathrm{Al}^{3+}$ toxicity.

In addition to the change in cross-section structure of cells, the longitudinal cell arrangement was disordered, the cell shapes were distorted from a rectangle into an irregular shape, and the cell size was enlarged in the cortex and even in the stele of the TZ and EZ. The cell structure changes in the longitudinal direction coincided with the distribution of IAA fluorescence signal intensities in the longitudinal direction of the cortex and stele; in which, the dotted lines of IAA fluorescence signals were discontinuous and disordered. These longitudinal changes in cell structure might inhibit IAA down-transport from the upper root to root tips through the stele, as well as backflow through the epidermis and outer cortex cells and lead to an imbalance in IAA accumulation in root tips. Meanwhile, $\mathrm{Al}^{3+}$ stress promoted differentiation of the root meristematic zone and shorted the length of the MZ, which led to an early appearance of the TZ and EZ, as well as the cells in the TZ and EZ were seriously enlarged. Doncheva et al. ${ }^{39}$ reported that $\mathrm{Al}^{3+}$ ions could inhibit cell division in the proximal meristem $(250-800 \mu \mathrm{m}$ from the tip), but stimulated cell division in the elongation zone of the root tip. Thus, the meristematic zone was very 

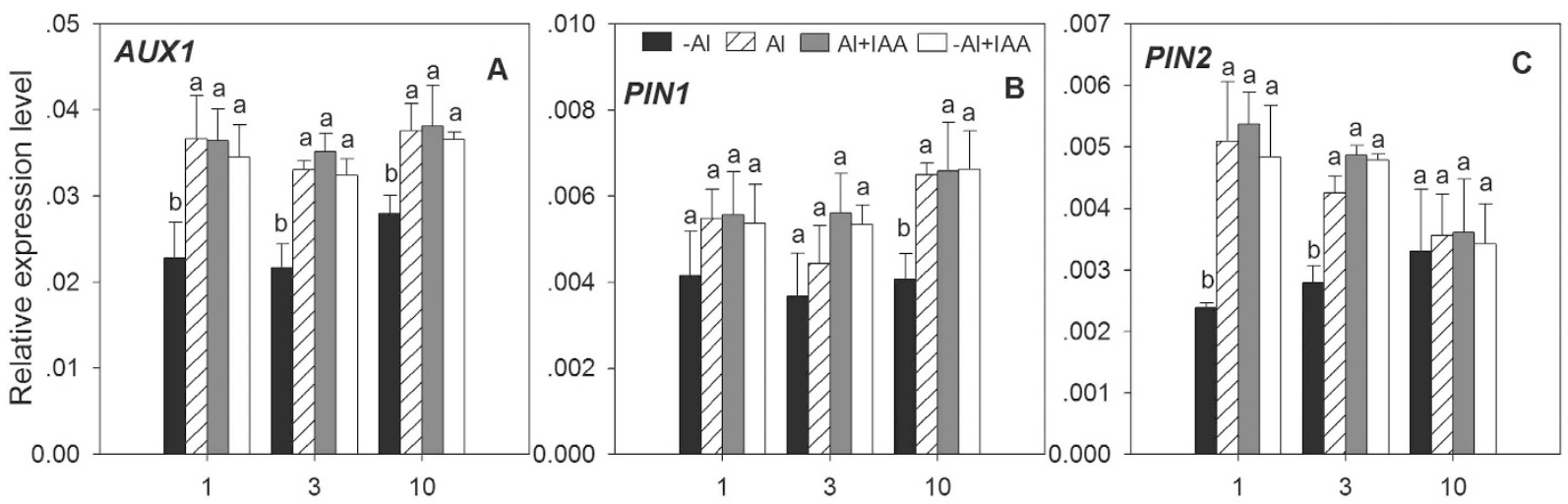

Days of $\mathrm{Al}^{3+}$ treatment

Figure 8. Expression of $A U X 1, P I N 1$ and PIN2 in root tips $(0-10 \mathrm{~mm})(\mathbf{A}-\mathbf{C})$ of alfalfa seedlings grown for $1,3$ and 10 days on $1 / 2$-strength Hoagland's medium ( $\mathrm{pH} 4.5)$ in the treatments of no aluminium (-Al) and aluminium stress $\left.(\mathrm{Al})(100 \mu \mathrm{M} \mathrm{AlCl})_{3}\right)$ aluminium with additional IAA $(\mathrm{Al}+\mathrm{IAA})\left(100 \mu \mathrm{M} \mathrm{AlCl}_{3}+\mathrm{IAA}\right)$ and -Al with additional IAA (-Al $+\mathrm{IAA})$. Data are means $\pm \mathrm{SE}$ of three replicates. Bars with different letters indicate a significant difference at $P<0.05$ (least significant difference test).

sensitive to $\mathrm{Al}^{3+}$, and the cell division inhibition in $\mathrm{MZ}$ directly reduced the amount of new cell supplement in roots, as a consequence, fundamentally restricted root elongation.

Callose ( $\beta-1,3$ binding glucan), a sensitive marker of $\mathrm{Al}^{3+}$ sensitivity, was quickly induced in the epidermis and cortex in $\mathrm{Al}^{3+}$-stressed plants. It was deposited along the plasmodesmata sleeve and blocked symplastic transport and communication ${ }^{5,36,40}$. The Al-induced callose accumulation in shoots and root tips blocked auxin movement down the stele to the root tips as well as the backward flow to the upper root in the epidermis and outer cortex cell, leading to a disturbed IAA distribution in root tips.

The accumulation of auxin in the root tip is mediated by its biosynthesis and transport ${ }^{10,29}$. Polar auxin transport is the central rate-limiting component of auxin transport ${ }^{29,41}$. Polar auxin transport in the root epidermis requires PIN2 and AUX1 ${ }^{41,42}$. PIN2 plays a pivotal role in mediating the backward (towards the root base) auxin flow in the epidermis and outer cortex of cells ${ }^{43}$. The AUX1 gene encodes a transmembrane protein and is believed to be associated with the influx of auxin across the plasma membrane $e^{42}$. Transcriptional analysis demonstrated that PIN2 and $A U X 1$ were up-regulated in root tips exposed to $\mathrm{Al}^{3+}$, positively mediating polar auxin transport from the QC of root tips to the upper root, leading to a higher IAA accumulation in the epidermis and cortex of the meristematic zone; this was reflected by higher intensity of IAA fluorescence signals. Because the cell structure and arrangement in the cortex of the TZ and EZ were changed, and aluminum-induced cell change would alter cell cytoskeleton ${ }^{8}$, the auxin transport within both cells and inter-cellularly might be affected ${ }^{35,44}$. Therefore, the IAA fluorescence signals discontinued in the cortex in the TZ and the backward IAA transport was blocked, leading to a higher auxin accumulation in the meristematic zone.

PIN1 is another gene functioning in polar auxin transport and helps auxin flow from apical buds to the root tips through the stele ${ }^{10}$. Transcription of this gene was up-regulated in $\mathrm{Al}^{3+}$-stressed roots in the present study. This finding suggests that the PIN1 regulation of polar auxin transport through the stele was not affected by $\mathrm{Al}^{3+}$ stress in alfalfa and that the reduction of IAA transport through the stele to root tips may be regulated by other mechanisms in which the $\mathrm{Al}^{3+}$-induced cellular changes in arrangement, shape, size, maturity, inner structure and components would be important mechanisms for inhibiting IAA transport in root tips.

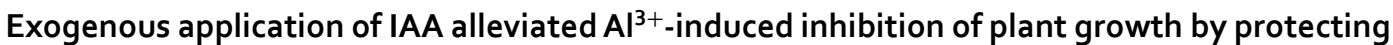
cell structure in root tips. Growth reduction due to excess $\mathrm{Al}^{3+}$ is a common feature in most plant species ${ }^{2}$. In the present study, $\mathrm{Al}^{3+}$ caused a reduction in root length, root weight, root activity, and total chlorophyll content in leaves. This was in agreement with several previous studies ${ }^{45}$. The $\mathrm{Al}^{3+}$-induced inhibition of root growth and damage in physiology, however, was significantly alleviated by exogenous application of IAA. Accumulation of IAA in root tips is essential for root growth in conditions of excessive metal stress ${ }^{46,47}$. Exogenous application of auxin alleviated cadmium toxicity in Arabidopsis due to its compensation for the lack of auxin in the root tips ${ }^{48}$. Exogenous application of IAA protected the cell structures of $\mathrm{Al}^{3+}$-stressed root tips (cell arrangement, cell shape and cell size); consequently, it restored the convenient array of IAA fluorescence signals in the form of a dotted line and balanced the distribution of IAA fluorescence signals in different zones of the root tip. Those results suggested that the $\mathrm{Al}^{3+}$-induced inhibition of alfalfa growth could be alleviated by auxin through reducing the cell structure damage in root tips.

In conclusion, our results demonstrated that IAA played a key role in alfalfa responses to $\mathrm{Al}^{3+}$ stress. IAA synthesis and transport in alfalfa was sensitive to $\mathrm{Al}^{3+}$ stress, as exhibited by the quick decrease in IAA concentrations in apical buds, shoot base and root tips of alfalfa seedlings in response to $\mathrm{Al}^{3+}$ stress. The significant reduction of IAA accumulation in apical buds and root tips, as well as the imbalance of IAA distribution among the meristematic zone, transition zone and elongation zone of $\mathrm{Al}^{3+}$-stressed root tips may be the fundamental factors attributed to the restriction of plant growth by $\mathrm{Al}^{3+}$ stress. $\mathrm{Al}^{3+}$ stress caused serious damage to the cell structure in terms of 
cell arrangement, shape, size, maturity, inner structure and components, which strongly disturbed IAA transport in root tips. Moreover, exogenous application of IAA could partly alleviate this disturbance, restore the convenient array of IAA fluorescence signals, enhance IAA accumulation in root tips, and increase root growth.

\section{Material and Methods}

Plant materials and growth conditions. An $\mathrm{Al}^{3+}$-tolerant alfalfa genotype, WL-525HQ ${ }^{49}$, was obtained from the Chinese National Seed Group Corporation, Ltd. and was used in this study. Seeds were soaked in distilled water for $1 \mathrm{~h}$ and then germinated on a filter paper moistened regularly with $1 / 2$-strength Hoagland's nutrient solution in a growth chamber at a temperature of $25^{\circ} \mathrm{C}$. After six days, uniform seedlings were transplanted to a foam board ( 12 holes/plate; 6 seedlings/hole) floating on an aerated 1/2-strength Hoagland's nutrient solution ( $\mathrm{pH}$ 5.8) in plastic containers. The composition of Hoagland's nutrient solution is $2.5 \mathrm{mM} \mathrm{KNO}_{3}, 0.5 \mathrm{mM}$ $\mathrm{NH}_{4} \mathrm{NO}_{3}, 1 \mathrm{mM} \mathrm{MgSO}_{4}, 0.5 \mathrm{mM} \mathrm{KH}_{2} \mathrm{PO}_{4}, 2 \mathrm{mM} \mathrm{Ca}\left(\mathrm{NO}_{3}\right)_{2}, 25 \mu \mathrm{M} \mathrm{FeSO}_{4}, 25 \mu \mathrm{M} \mathrm{Na}_{2}$-EDTA, $2.5 \mu \mathrm{M} \mathrm{KI}, 50 \mu \mathrm{M}$ $\mathrm{MnSO}_{4}, 50 \mu \mathrm{M} \mathrm{H}_{3} \mathrm{BO}_{3}, 0.05 \mu \mathrm{M} \mathrm{CuSO}_{4}, 15 \mu \mathrm{M} \mathrm{ZnSO}_{4}, 0.5 \mu \mathrm{M} \mathrm{NaMoO}_{4}$ and $0.05 \mu \mathrm{M} \mathrm{CoCl}{ }_{2}$. Solutions were renewed every $2 \mathrm{~d}$, and all seedlings were grown in growth chambers with a temperature of $25 / 20^{\circ} \mathrm{C}$ (day/night), a 14-h photoperiod, photon flux density of $400 \mu \mathrm{mol} \mathrm{m}^{-2} \mathrm{~s}^{-1}$ and a relative humidity of $65 \%$. Four days after transplanting (10 d after sowing), seedlings were used for the following treatments in the same growth chambers.

Treatments and Experimental Design. For aluminium toxicity treatments, seedlings were treated with $1 / 2$-strength Hoagland's solution ( $\mathrm{pH} 4.5$ ) supplemented with 0 (-Al) or $100 \mu \mathrm{M} \mathrm{AlCl}_{3}(\mathrm{Al}$ ) (Supplementary Fig. 1) for 1,3 and $10 \mathrm{~d}$, and then plant samples were collected for further analysis. For root tip $(1-10 \mathrm{~mm})$ collection, both the main root tips and the secondary root tips were collected. For IAA treatments, plants exposed to 0 (-Al) or $100 \mu \mathrm{M} \mathrm{AlCl}_{3}(\mathrm{Al})$ were foliar sprayed with $2 \mathrm{ml}$ of $6 \mathrm{mg} \mathrm{L}^{-1}$ IAA (Sigma, MO, USA) every two days, which comprised the $-\mathrm{Al}+\mathrm{IAA}$ and $\mathrm{Al}+\mathrm{IAA}$ treatments, and the control plants were sprayed with $2 \mathrm{ml}$ water ( $\mathrm{pH} 6.0)$. The $6 \mathrm{mg} \mathrm{L}^{-1}$ IAA concentration used for foliar spraying was selected from a preliminary experiment showing positive effects on mitigating $\mathrm{Al}^{3+}$ stress $^{50}$. After 1,3 and $10 \mathrm{~d}$ of IAA treatment, plant samples were collected for further analysis.

For microscopy study and immunohistochemical analysis of IAA in root tips, the alfalfa seeds were germinated in $1 / 2$-strength Hoagland's nutrient solution for $60 \mathrm{~h}$ and then supplemented with $0(-\mathrm{Al})$ or $100 \mu \mathrm{M} \mathrm{AlCl}_{3}$ (Al) for 1,3 , and 10 days; the root tips $(0-8 \mathrm{~mm})$ were then cut for the microscopy study and immunohistochemical analysis.

In the apical buds removal experiment, to analyze the effect of $\mathrm{Al}^{3+}$ stress on IAA synthesis in apical buds, seedlings were divided into two groups: apical bud intact and apical bud removed. Apical buds of seedlings in the latter group were removed before being treated with aluminium and IAA. Each group was treated with aluminium and IAA using the method previously described for $24 \mathrm{~h}$ and was then sampled for IAA measurement.

To determine whether the deficiency of $\mathrm{Zn}^{2+}$ and $\mathrm{Mg}^{2+}$ in $\mathrm{Al}^{3+}$-stressed alfalfa influenced auxin synthesis, we designed the following treatments. After the first leaf of seedlings emerged under the growth condition of $1 / 2$-strength Hoagland's nutrient solution, roots of the seedlings were washed with deionized water and grown for $12 \mathrm{~h}$ in deionized water. Seedlings were then grown for $24 \mathrm{~h}$ in $0.5 \mathrm{mM} \mathrm{Ca}^{2+}$ solution ( $\left.\mathrm{pH} 4.5\right)$ with 0 (-Al) or $100 \mu \mathrm{M} \mathrm{AlCl}_{3}(\mathrm{Al})$. Among the $\mathrm{Al}^{3+}$ treatments, some of the plants received $25 \mu \mathrm{M}$ or $50 \mu \mathrm{M} \mathrm{MgCl}_{2}$ for the $\mathrm{Mg}^{2+}$ treatment, and $25 \mu \mathrm{M}$ or $50 \mu \mathrm{M} \mathrm{ZnCl}_{2}$ for the $\mathrm{Zn}^{2+}$ treatment.

Physiological analysis. After 1, 3 and $10 \mathrm{~d}$ of treatment with aluminium and IAA, 10 plants from each container were separated into shoots and roots. The fresh weight of shoots was measured. Roots were blotted dry with paper towels and then weighed to determine the root fresh weight. Root length was measured from the root tip to the base of the main root. Membrane lipid peroxidation, expressed as malondialdehyde (MDA) content, was determined using the thiobarbituric acid (TBA) protocol ${ }^{51}$. Chlorophyll content was estimated according to the procedure described by Porra et al. ${ }^{52}$. Root activity was measured using the triphenyltetrazolium chloride (TTC) reduction method as described by Islam et al. ${ }^{53}$.

Microscopy investigation. The collected root tips were immediately fixed in $2.5 \%$ (v/v) glutaraldehyde and $4 \%$ paraformaldehyde (Electron Microscopy Sciences) in PBS, pH 7.2, for $48 \mathrm{~h}$ at $4{ }^{\circ} \mathrm{C}$. Samples were then washed with PBS, dehydrated in a graded ethanol series, and embedded in LR White resin (Ted Pella Inc.). Transverse and longitudinal sections $(1 \mu \mathrm{m})$ were cut with a diamond knife on a Leica EM UC6 ultramicrotome (Leica Mikrosysteme). For Toluidine Blue O staining, 1- $\mu \mathrm{m}$ semi-thin sections were placed onto glass slides, stained with $1 \%(\mathrm{w} / \mathrm{v})$ Toluidine Blue $\mathrm{O}$ (with $1 \%$ [w/v] sodium borate) for $5 \mathrm{~min}$, and observed under a microscope (Olympus IX71, Olympus Optical Co. Ltd, Tokyo, Japan). The meristem length of the root tips was measured from the quiescent centre to the cortical cells, which are rapidly elongated, as described by Blilou et al. ${ }^{41}$. The meristem width was measured in the middle of the meristematic zone. The results presented are average values of more than 30 seedlings per treatment from three independent experiments.

Immunohistochemical Analysis. Auxin immunolocalization was performed as described by Nishimura et al. ${ }^{54}$ and Watanabe et al. ${ }^{55}$. Excised root tips were immediately fixed in $4 \%$ 1-ethyl-3-(dimethylaminopropyl)-carbodiimide hydrochloride (EDAC) and $4 \%$ paraformaldehyde for $24 \mathrm{~h}$ at $4{ }^{\circ} \mathrm{C}$. Samples were then dehydrated in a graded ethanol series, infiltrated with xylene, and embedded in paraffin wax using conventional methods. Material sections were cut to thicknesses of $10 \mu \mathrm{m}$ and pasted onto poly-lysine slides. The sections were then treated in a blocking solution consisting of $10 \mathrm{mM}$ PBS/Tween-20/glycine/bovine serum albumin (BSA) $(93.5 / 0.1 / 1.5 / 5, \mathrm{v} / \mathrm{v} / \mathrm{w} / \mathrm{w})$ for $45 \mathrm{~min}$, rinsed in regular-salt rinse solution (RSR) containing $10 \mathrm{mM}$ PBS/Tween20/BSA/ $\mathrm{NaCl}(98 / 0.1 / 0.8 / 0.88, \mathrm{v} / \mathrm{v} / \mathrm{w} / \mathrm{w})$ for $5 \mathrm{~min}$, and treated with an additional solution containing $10 \mathrm{mM}$ $\mathrm{PBS} /$ Triton X-100/BSA $(99 / 0.8 / 0.1, \mathrm{v} / \mathrm{v} / \mathrm{w})$. Subsequently, the tissue sections were incubated in the primary rabbit polyclonal antibody to IAA (Abcam, UK) in the dark at $37^{\circ} \mathrm{C}$ for $30 \mathrm{~min}$. They were then washed in a high-salt 


\begin{tabular}{|l|l|l|c|}
\hline Gene & Forward sequence & Reverse sequence & GenBank accession \\
\hline Elongation factor 1- $\alpha(E F 1-\alpha)$ & $5^{\prime}$-GCACCAGTGCTCGATTGC-3' & $5^{\prime}$-TCGCCTGTCAATCTTGGTAACAA-3' & XM_003618727 \\
\hline Auxin transporter-like protein $($ AUX1) & 5'-GACTACATACACTGCTTGGT-3' $^{\prime}$ & $5^{\prime}$-AGTGGCAGAAGGAATCGTTA-3' & XM_003623180 \\
\hline Auxin efflux carrier components 2 (PIN2) & 5'-GATGCTGGTCTTGGAATGGC-3' $^{\prime}$ & $5^{\prime}$-ATTGCTATTGAGGTTGCCGC-3' & XM_003609978 \\
\hline Auxin efflux carrier components 1 (PIN1) & 5'-GCTTCACCTGTCTCTGATGTG-3' $^{\prime}$ & $5^{\prime}$-CCACCTTTCTCACCTCCTTC-3' & XM_003619781 \\
\hline
\end{tabular}

Table 2. Primer sequences used for Q-PCR.

rinse solution consisting of $10 \mathrm{mM} \mathrm{PBS} /$ Tween-20/BSA/ $\mathrm{NaCl}(97 / 0.1 / 0.1 / 2.9, \mathrm{v} / \mathrm{v} / \mathrm{w} / \mathrm{w})$. After several rinses in RSR and PBS, the tissue sections were incubated with the secondary antibody (anti-rabbit IgG Alexa Fluor 488-conjugate; Protein tech Group, Chicago, IL, USA) and were detected immune signals at $495 \mathrm{~nm}$. Fluorescence was detected with a laser-scanning confocal microscope (Leica TCS SP5II).

Indole-3-acetic acid was extracted and purified according to the method described by Yan et al. ${ }^{56}$ with some modifications. A $0.5-\mathrm{g}$ fresh sample was ground in liquid nitrogen, and then $5 \mathrm{ml}$ pre-cooled $\left(-20^{\circ} \mathrm{C}\right) 80 \%$ methanol (containing $10 \mathrm{mg} \mathrm{L}^{-1} \mathrm{BHT}$, w/v) was added to the sample. After overnight extraction at $-20^{\circ} \mathrm{C}$, solids were separated by centrifugation $(20,000 \mathrm{~g}, 15 \mathrm{~min})$ and re-extracted for $30 \mathrm{~min}$ in an additional $5 \mathrm{ml}$ of the same extraction solution. Then, the supernatants were concentrated to $2.0 \mathrm{ml}$ and were passed through a Sep-Pak Plus C18 cartridge (SepPak Plus, Waters, USA). After washing with $3 \mathrm{ml} 20 \%$ methanol containing $1 \%(\mathrm{v} / \mathrm{v})$ acetic acid, the cartridges were eluted with $1 \mathrm{ml}$ pure methanol for HPLC measurement. The determination was repeated at least three times. Analyses were carried out on a Shimadzu LC-10A HPLC (Shimadzu, Kyoto, Japan) system equipped with an SPD-10Avp detector.

Callose content was measured according to the method described by Jones et al. ${ }^{36}$

Gene expression analysis. Three genes related to auxin transport were examined with quantitative PCR (Q-PCR): auxin transporter-like protein (AUX1), and auxin efflux carrier components 1 and 2 (PIN1 and PIN2). Total RNA was isolated using Trizol (Invitrogen). The first-strand cDNA was synthesized with a PrimeScript RT reagent kit (Takara) using oligo (dT) primers. For real-time RT-PCR analysis, $1 \mu \mathrm{l} 10$-fold-diluted cDNA was used for quantitative analysis of gene expression performed with SYBR Premix ExTaq (Takara) with the specific primers (Table 2).

Reactions were run on an ABI PRISM 5700 Sequence Detector (Applied Biosystems). Elongation factor 1- $\alpha$ $(E F 1-\alpha)$ was selected as an endogenous control. Each gene was examined three times. All PCR efficiencies were above 95\%. Sequence Detection Software (version 1.3, Applied Biosystems) results were exported as tab-delimited text files and imported into Microsoft Excel (Redmond, WA, USA) for further analysis. The median coefficient of variation (based on calculated quantities) of duplicated samples was $6 \%$.

Statistical analysis. The data were subjected to analysis of variance (ANOVA), and the least significant difference (LSD) test was employed to determine differences among the treatments at $P=0.05$ levels.

\section{References}

1. Kochian, L. V. Cellular mechanisms of aluminum toxicity and resistance in plants. Annu. Rev. Plant Biol. 46, 237-260 (1995).

2. Kochian, L. V., Hoekenga, O. A. \& Piñeros, M. A. How do crop plants tolerate acid soils? Mechanisms of aluminum tolerance and phosphorous efficiency. Annu. Rev. Plant Biol. 55, 459-493 (2004).

3. Ryan, P. R., Ditomaso, J. M. \& Kochian, L. V. Aluminium toxicity in roots: an investigation of spatial sensitivity and the role of the root cap. J. Exp. Bot. 44, 437-446 (1993).

4. Matsumoto, H. Cell biology of aluminum toxicity and tolerance in higher plants. Int. Rev.Cytol. 200, 1-46 (2000).

5. Sivaguru, M., Baluška, F., Volkmann, D., Felle, H. H. \& Horst, W. J. Impacts of aluminum on the cytoskeleton of the maize root apex. Short-term effects on the distal part of the transition zone. Plant Physiol. 119, 1073-1082 (1999).

6. Horst, W. J., Wang, Y. \& Eticha, D. The role of the root apoplast in aluminium-induced inhibition of root elongation and in aluminium resistance of plants: a review. Ann. Bot-London 106, 185-197 (2010).

7. Kollmeier, M., Felle, H. H. \& Horst, W. J. Genotypical differences in aluminum resistance of maize are expressed in the distal part of the transition zone. Is reduced basipetal auxin flow involved in inhibition of root elongation by aluminum? Plant Physiol. 122, 945-956 (2000).

8. Sivaguru, M. et al. Aluminum-induced $1 \rightarrow 3-\beta$-d-glucan inhibits cell-to-cell trafficking of molecules through plasmodesmata. A new mechanism of aluminum toxicity in plants. Plant Physiol. 124, 991-1006 (2000).

9. Ye, Y. Q. et al. Elevation of NO production increases Fe immobilization in the Fe-deficiency roots apoplast by decreasing pectin methylation of cell wall. Sci. Rep. 5, 10746 (2015).

10. Vanneste, S. \& Friml, J. Auxin: a trigger for change in plant development. Cell 136, 1005-1016 (2009).

11. Yu, Y. et al. Inhibition of ethylene production by putrescine alleviates aluminium-induced root inhibition in wheat plants. Sci. Rep. 6, 18888 (2016).

12. Xu, J. et al. Exogenous nitric oxide improves antioxidative capacity and reduces auxin degradation in roots of Medicago truncatula seedlings under cadmium stress. Plant soil 326, 321-330 (2010).

13. Hu, Y. F. et al. Cadmium interferes with maintenance of auxin homeostasis in Arabidopsis seedlings. J. Plant Physiol. 170, $965-975$ (2013).

14. Yuan, H. M. \& Huang, X. Inhibition of root meristem growth by cadmium involves nitric oxide-mediated repression of auxin accumulation and signaling in Arabidopsis. Plant cell environ. 39, 120-135 (2015)

15. Krishnamurthy, A. \& Rathinasabapathi, B. Auxin and its transport play a role in plant tolerance to arsenite-induced oxidative stress in Arabidopsis thaliana. Plant cell environ. 36, 1838-1849 (2013).

16. Yuan, H.-M., Xu, H.-H., Liu, W.-C. \& Lu, Y.-T. Copper regulates primary root elongation through PIN1-mediated auxin redistribution. Plant Cell Physiol. 54, 766-778 (2013).

17. Nomura, T. et al. Copper mediates auxin signalling to control cell differentiation in the copper moss Scopelophila cataractae. J. Exp. Bot. 66, 1205-1213 (2015).

18. Hartel, P. \& Bouton, J. Rhizobium meliloti inoculation of alfalfa selected for tolerance to acid, aluminum-rich soils. Plant soil 116, 283-285 (1989) 
19. Narasimhamoorthy, B., Bouton, J., Olsen, K. \& Sledge, M. Quantitative trait loci and candidate gene mapping of aluminum tolerance in diploid alfalfa. Theor. Appl. Genet (TAG). 114, 901-913 (2007).

20. Zhou, P., Yang, F., Ren, X., Huang, B. \& An, Y. Phytotoxicity of aluminum on root growth and indole-3-acetic acid accumulation and transport in alfalfa roots. Environ. Exp. Bot. 104, 1-8 (2014).

21. Peleg, Z. \& Blumwald, E. Hormone balance and abiotic stress tolerance in crop plants. Curr.Opin.Plant Biol. 14, 290-295 (2011).

22. Versees, W., Spaepen, S., Vanderleyden, J. \& Steyaert, J. The crystal structure of phenylpyruvate decarboxylase from Azospirillum brasilense at 1.5 Å resolution. FEBS J. 274, 2363-2375 (2007).

23. Bybordi, A. \& Shabanov, J. A. Effects of the foliar application of magnesium and zinc on the yield and quality of three grape cultivars grown in the calcareous soils of iran. Not. Bot. Horti. Agrobo. 2, 81-86 (2010).

24. Silva, S. et al. Differential aluminium changes on nutrient accumulation and root differentiation in an $\mathrm{Al}$ sensitive vs. tolerant wheat. Environ. Exp. Bot. 68, 91-98 (2010).

25. An, Y., Zhou, P., Xiao, Q. \& Shi, D. Effects of foliar application of organic acids on alleviation of aluminum toxicity in alfalfa. J. Plant Nutr. Soil Sc. 177, 421-430 (2014).

26. Bose, J., Babourina, O. \& Rengel, Z. Role of magnesium in alleviation of aluminium toxicity in plants. J. Exp. Bot. 62, 2251-2264 (2011).

27. Deng, W. et al. Overexpression of an Arabidopsis magnesium transport gene, AtMGT1, in Nicotiana benthamiana confers $\mathrm{Al}$ tolerance. J. Exp. Bot. 57, 4235-4243 (2006).

28. Ahn, S. J., Sivaguru, M., Osawa, H., Chung, G. C. \& Matsumoto, H. Aluminum inhibits the $\mathrm{H}^{+}$-ATPase activity by permanently altering the plasma membrane surface potentials in squash roots. Plant physiol. 126, 1381-1390 (2001).

29. Band, L. R. et al. Systems analysis of auxin transport in the arabidopsis root apex. Plant Cell 26, 862-875 (2014)

30. Kerk, N. M., Jiang, K. N. \& Feldman, L. J. Auxin metabolism in the root apical meristem. Plant physiol. 122, 925-932 (2000).

31. Ponce, G., Barlow, P. W., Feldman, L. J. \& Cassab, G. I. Auxin and ethylene interactions control mitotic activity of the quiescent centre, root cap size, and pattern of cap cell differentiation in maize. Plant cell environ. 28, 719-732 (2005).

32. Čiamporová, M. Morphological and structural responses of plant roots to aluminium at organ, tissue, and cellular levels. Biol. Plantarum 45, 161-171 (2002).

33. Gunsé, B., Garzón, T. \& Barceló, J. Study of aluminum toxicity by means of vital staining profiles in four cultivars of Phaseolus vulgaris L. J. Plant Physiol. 160, 1447-1450 (2003).

34. Bakos, F. et al. A cytological study on aluminium-treated wheat anther cultures resulting in plants with increased Al tolerance. Plant breeding 127, 235-240 (2008).

35. Arroyave, C., Barceló, J., Poschenrieder, C. \& Tolrà, R. Aluminium-induced changes in root epidermal cell patterning, a distinctive feature of hyperresistance to $\mathrm{Al}$ in Brachiaria decumbens. J. Inorg. Biochem. 105, 1477-1483 (2011).

36. Jones, D. L., Blancaflor, E. B., Kochian, L. V. \& Gilroy, S. Spatial coordination of aluminium uptake, production of reactive oxygen species, callose production and wall rigidification in maize roots. Plant cell environ. 29, 1309-1318 (2006).

37. Kochian, L. V., Piñeros, M. A., Liu, J. \& Magalhaes, J. V. Plant Adaptation to Acid Soils: The Molecular Basis for Crop Aluminum Resistance. Annu. Rev. Plant Biol. 66, 571-598 (2015).

38. Čiamporová, M. Diverse responses of root cell structure to aluminium stress. Plant Soil 226, 113-116 (2000).

39. Doncheva, S., Amenós, M., Poschenrieder, C. \& Barceló, J. Root cell patterning: a primary target for aluminium toxicity in maize. J. Exp. Bot. 56, 1213-1220 (2005).

40. Sun, C. et al. Decreasing methylation of pectin caused by nitric oxide leads to higher aluminium binding in cell walls and greater aluminium sensitivity of wheat roots. J. Exp. Bot. 67, 979-989 (2015).

41. Blilou, I. et al. The PIN auxin efflux facilitator network controls growth and patterning in Arabidopsis roots. Nature 433, 39-44 (2005).

42. Habets, M. E. \& Offringa, R. PIN-driven polar auxin transport in plant developmental plasticity: a key target for environmental and endogenous signals. New Phytol. 203, 362-377 (2014).

43. Sun, P., Tian, Q.-Y., Chen, J. \& Zhang, W.-H. Aluminium-induced inhibition of root elongation in Arabidopsis is mediated by ethylene and auxin. J. Exp. Bot. 61, 347-356 (2010).

44. Illéš, P. et al. Aluminium toxicity in plants: internalization of aluminium into cells of the transition zone in Arabidopsis root apices related to changes in plasma membrane potential, endosomal behaviour, and nitric oxide production. J. Exp. Bot. 57, 4201-4213 (2006).

45. Yang, Z.-B. et al. TAA1-Regulated Local Auxin Biosynthesis in the Root-Apex Transition Zone Mediates the Aluminum-Induced Inhibition of Root Growth in Arabidopsis. Plant Cell 114, 2889-2904 (2014).

46. Chen, W. W. et al. Nitric oxide acts downstream of auxin to trigger root ferric-chelate reductase activity in response to iron deficiency in Arabidopsis. Plant Physiol. 154, 810-819 (2010).

47. Martín-Rejano, E. M. et al. Auxin and ethylene are involved in the responses of root system architecture to low boron supply in Arabidopsis seedlings. Physiol. Plantarum 142, 170-178 (2011).

48. Zhu, X. F. et al. Exogenous auxin alleviates cadmium toxicity in Arabidopsis thaliana by stimulating synthesis of hemicellulose 1 and increasing the cadmium fixation capacity of root cell walls. J. Hazard. Mater. 263, 398-403 (2013).

49. Pan, X.-B., Zhu, C. \& Cheng, C. Assessment of techniques for screening alfalfa cultivars for aluminum tolerance. Euphytica 164, 541-549 (2008).

50. Ren, X. Y., Zhou, P. \& An, Y. Effects of exogenous application of IAA on alleviate aluminum toxicity in alfalfa Seedlings. Pratacultural science 7, 1323-1329 (2013).

51. Peever, T. L. \& Higgins, V. J. Electrolyte leakage, lipoxygenase, and lipid peroxidation induced in tomato leaf tissue by specific and nonspecific elicitors from Cladosporium fulvum. Plant Physiol. 90, 867-875 (1989).

52. Porra, R., Thompson, W. \& Kriedemann, P. Determination of accurate extinction coefficients and simultaneous equations for assaying chlorophylls $\mathrm{a}$ and $\mathrm{b}$ extracted with four different solvents: verification of the concentration of chlorophyll standards by atomic absorption spectroscopy. (BBA)-Bioenergetics 975, 384-394 (1989).

53. Islam, E. et al. Effect of $\mathrm{Pb}$ toxicity on root morphology, physiology and ultrastructure in the two ecotypes of Elsholtzia argyi. $J$. Hazard. Mater. 147, 806-816 (2007).

54. Nishimura, T. et al. Immunohistochemical observation of indole-3-acetic acid at the IAA synthetic maize coleoptile tips. Plant Signal. Behav. 6, 2013-2022 (2011).

55. Watanabe, C. et al. Gravistimulation changes the accumulation pattern of the CsPIN1 auxin efflux facilitator in the endodermis of the transition zone in cucumber seedlings. Plant Physiol. 158, 239-251 (2012).

56. Yan, H., Wang, F., Han, D. \& Yang, G. Simultaneous determination of four plant hormones in bananas by molecularly imprinted solid-phase extraction coupled with high performance liquid chromatography. Analyst 137, 2884-2890 (2012).

\section{Acknowledgements}

This work was financially supported by the National Natural Science Foundation of China (No. 31572451 and No. 31272198), the Science and Technology Commission of Shanghai (No. 13JC1403200 and 15391912400), and Committee of Shanghai agriculture (No. 2013-5-10). 


\section{Author Contributions}

S.W. conceived, designed and performed all experiments, analyzed the data and wrote the manuscript. X. R. helped in preparing Figures 4-6. G.W. helped in preparing Figure 2. B.H. revised the manuscript. Y.A. and P.Z. monitored the experimental work and critically commented on the manuscript. All authors read and approved the final manuscript.

\section{Additional Information}

Supplementary information accompanies this paper at http://www.nature.com/srep

Competing financial interests: The authors declare no competing financial interests.

How to cite this article: Wang, S. et al. Aluminium-induced reduction of plant growth in alfalfa (Medicago sativa) is mediated by interrupting auxin transport and accumulation in roots. Sci. Rep. 6, 30079; doi: 10.1038/ srep30079 (2016).

(c) (i) This work is licensed under a Creative Commons Attribution 4.0 International License. The images or other third party material in this article are included in the article's Creative Commons license, unless indicated otherwise in the credit line; if the material is not included under the Creative Commons license, users will need to obtain permission from the license holder to reproduce the material. To view a copy of this license, visit http://creativecommons.org/licenses/by/4.0/ 